УДК 811.111'373.7:159.923.3

\title{
SOMATIC IDIOMS DESCRIBING TRAITS OF CHARACTER IN TEACHING ENGLISH
}

\author{
Yuliia Yelovska \\ Криворізький державний педагогічний університет \\ Kryvyi Rih State Pedagogical University \\ nр. Гагаріна, 54, Кривий Ріг, 50086, Україна \\ julia.yelovska@gmail.com
}

Єловська Ю. Фразеологізми із соматичним компонентом на позначення рис характеру людини у вивченні англійської мови

У статті розглядається компонентний склад, структура i вживання фразеологізмів із соматичним компонентом на позначення рис характеру людини у вивченні іноземної мови, англійської зокрема. Проаналізовано стійкі словосполучення англійської й української мов, які описують такі риси характеру людини як-от: доброта, агресивність, балакучість, мовчазність, допитливість. Виявлено, що більшість фразеологічних одиниць характеризується спільністю центральних соматичних елементів, виражених іменниками на позначення назв частин тіла людини (голова, рот, очі, серце, язик).

Ключові слова: фразеологізм, соматичний компонент, іноземна мова.

Еловская Ю. Фразеологизмы с соматическим компонентом, обозначающие черты характера человека в процессе изучения английского языка

В статье рассматривается компонентный состав, структура, а также использование фразеологизмов с соматическим компонентом, определяющих черты характера человека в процессе изучения иностранного языка, в частности английского. Проанализированы устойчивые выражения английского и украинского языков, описывающие такие черты характера как доброта, агрессивность, болтливость молчаливость и любопытство. Выяснено, что большинство фразеологических единиц характеризуется сходством центральных соматических элементов, которые выражаются существительными, обозначающими названия частей тела человека (голова, рот, глаза, сердце, язык).

Ключевые слова: фразеологизм, соматический компонент, иностранный язык.

Yelovska Yu. Somatic idioms describing traits of character in teaching English

The change of general scientific paradigm to the anthropological stream activates the interest of specialists in different areas to investigate the humanoriented problems, especially in linguistics and phraseology. Outlining previous research it should be mentioned that different aspects of somatic phraseologisms are 
investigated in the works of I. Denysenko, V. Hmara, G. Kozorih, Yu. Lapuhina, L. Moiseienko, N. Skorobagatko, F. Vakk and others. However these studies do not cover all the peculiarities of somatic idioms and their usage in teaching foreign languages. This article makes the attempt to represent the importance of involving the knowledge of idiomatic expressions in teaching foreign languages, in particular on the basis of somatic idioms. The main tasks of this research include analyzing the structure and semantics of phraseologisms with somatic components, comparing them with their native language equivalents and implementing these samples into the process of teaching foreign languages, English in particular.

The analysis has shown that both languages manifest a great variety of samples containing somatic nominative components such as "eyes", "ears", "lips", "nose", "mouth", "heart", "tongue", "blood". Additionally it has been stated that revealing human traits of character these phraseologisms represent certain variations in their meaning as well as their structure. We have also concluded that such idioms can be a well designed material for illustrating stylistic differences and peculiarities in both languages. For our further studies we leave the issues outlining the peculiarities of English and Ukrainian phraseologisms defying traits of character containing nominative animistic elements.

Key words: phraseological unit, somatic component, foreign language.

\section{Setting the problem and its connection with important} research tasks. The change of general scientific paradigm to the anthropological stream activates the interest of specialists in different areas to investigate the human-oriented problems, especially in linguistics and phraseology. Phraseology issues have become the subject of studying in the national and foreign research. There is a considerable amount of papers focused on the theoretical principles and fundamentals of phraseologism defying and classifying. Recent studies make successful attempts to analyze and interpret semantics and compositional structure of different idiomatic expressions. Taking into account the present-day anthropological approach in research streams the interest to somatic idioms becomes quite obvious.

Analysis of recent research and publications. Outlining previous research it should be mentioned that different aspects of somatic phraseologisms are investigated in the works of I. Denysenko, V. Hmara, G. Kozorih, L. Moiseienko, N. Skorobagatko, F. Vakk and others. However these studies do not cover all the peculiarities of somatic idioms and their usage in teaching foreign languages. The meaning of the term "somatism" derives from Greek "soma" denoting "body" and evidently gives the idea of defying somatic idioms as "a phraseology unit with somatic component". Following L. Moiseienko

(c) Yu. Yelovska, 2019. 
they can be determined as the idiomatic expressions containing components nominating the part of the human body or organs, as well as certain natural actions, reactions and processes in their structure [Moiseienko / Мойсеєнко 2015 : 411]. The great interest of language specialists studying idioms with somatic component is generally explained by a considerable number of samples. Such a variety is justified by the principles of phraseologism athropometricity and anthropomorphic analogies existing in the human mind while his world exploration [Paten / Патен 2015 : 89].

The purpose and tasks of the research. This article makes the attempt to represent the importance of involving the knowledge of idiomatic expressions in teaching foreign languages, in particular on the basis of somatic idioms. The main tasks of this research include analyzing the structure and semantics of phraseologisms with somatic components, comparing them with their native language equivalents and implementing these samples into the process of teaching foreign languages, English in particular.

Presentation of the main research material. Teaching any foreign language requires from the lecturer not only to give the theoretical knowledge and improve language skills among future philologists, but also to develop a wide range of competences. The linguistic and cultural aspect is an important component in comprehensive language training of future foreign language (English) specialists. The education reforms adopted by the Ministry of Education and Science of Ukraine that have taken place in the recent years represent new trends in teaching foreign languages within different education levels. Among them the primary task is to implement an integrated approach in teaching foreign languages.

According to the above mentioned requirements it is necessary to include the linguistic and cultural information into the process of teaching English. The best way to show the peculiarities of foreign language world view to the non-native speakers is to enrich the traditional methods of training by means of applying foreign language idioms in comparison to their native language equivalents.

This paper is focused on describing the structure and meaning differences of set expressions with somatic components in English and Ukrainian. It should be mentioned that both languages manifest a 
great variety of samples containing somatic components. It can be explained by the common trend of world investigation by the human himself. Although revealing human traits of character these phraseologisms show certain variations in their meaning as well as their structure. It should be noted that the list of analyzed idioms has been selected due to the typical structure and nominative elements mostly nouns defying the organs or parts of the human body.

The main difficulty that arises while studying such set expressions is connected with the search of an appropriate native language equivalent. Taking into account that two languages show significant differences in the word stock and grammar, the peculiarities of language formation, language ethics and communication specificity, it becomes quite obvious that some idioms represent similar structure but wider range of meaning. On contrary the same meaning is shown by different word combinations including different core components.

Describing the traits of character both nations the British and Ukrainians use mostly the same elements denoting the parts of human body or face. Analyzing the selected English and Ukrainian phraseological units it has been noticed that the key nominative elements describing human traits of character are eyes, ears, lips, nose, mouth, heart, tongue, blood, etc.

Kindness is manifested by the idioms having the inner components represented by the noun "heart". Heart is considered to be the core element of these idioms obviously because this organ is associated with abilities to express emotions and show feelings positive in particular. Analyzing English set expressions defying a kind, emotional and sympathetic person their structural inhomogeneity is revealed. Despite the common feature of containing the core noun element these samples demonstrate different frames built up according to the following schemes: "noun + preposition + noun", "verb + noun", "preposition + noun". For instance: heart of gold (6, p. 102); one's heart bleeds (6, p. 111); with all heart (6, p. 123); from the bottom of one's heart (6, p. 97); heart in the right place (6, p. 140); to take to heart (6, p. 119). In case of involving this material into the language training the tutor should bear in mind that these idioms have the corresponding 
Ukrainian equivalents, mainly illustrated by the samples having the similar structure such as: золоте серие (4, p. 793); серие кров'ю обливається (4, р. 400); всім серием (4, р. 798); від щиирого / чистого серия (4, p. 800); брати до серия (4, p. 799). It should be noted that English set expressions do not show the same variety.

Moreover considering phraseology units of above mentioned languages, Ukrainian idioms demonstrate the higher level of productivity and diversity while defying a kind and sympathetic person and implemented in the attributive constructions: велике серие (4, р. 792); добре/ живе серие (4, р. 793); м'яке серие (4, p. 793); розм'якло серие (4, p. 794). In addition the Ukrainian word combinations with figurative meaning containing the "heart" component and built up in the frame of "noun + verb" represent a great variety of emotions fear, love, envy, joy, anxiety etc.: cepue холоне (4, р. 792); серце тремтить (4, р. 792); серце заграло (4, p. 793); серие запалало (4, р. 793); серие в'яне (4, p. 794); серие каменем лежить (4, р. 795); черв'як точить серие (4, p. 798); холодна жаба сидить на сериі (4, p. 799). We can assume that the following diversity can be explained by cordocentrism philosophical paradigm defying the heart as the centre of human existence, prevailing in the Ukrainian world view.

On contrary describing the person, who bears opposite characteristics such as agressiveness and the lack of sympathy in English and Ukrainian there are illustrations having dynamic core nominative elements. Unlike with the positive trait mainly presented by the set expressions with the noun "heart" English negative ones are revealed by means of other somatic nominations, in particular constructions including nouns "blood", "head", "mouth" or their derivatives. The structure of these phraseological units is also quite diverse: heart of stone (6, p. 102); hot-blooded (6, p. 28); to make one's blood boil (6, p. 29); from foam at the mouth (6, p. 117). Moreover their Ukrainian equivalents defining the same meaning use similar nouns “серце”, “голова", “кров”, “рот”: без серия (4, p. 799); кам'яне серие (4, р. 793); серие кам'яніс (4, р. 795) гаряча голова (4, р. 181); кров закипіла (4, p. 399); аж піна 3 рота скаче (4, p. 762); з піною в роті (4, p. 762). Similarity in component and structure construction of idioms in both languages 
can be explained due to similar observations of people being in the state of rage or anger.

Talkativeness is represented by the phraseology units containing the core somatic element expressed by the noun "tongue" and its derivatives introduced in the verbal constructions: to have a ready tongue (6, p. 100); to be loose-tongued (6, p. 89); to have a tongue that runs (6, p. 104); to have too much tongue (6, p. 102).

Ukrainian equivalents describing person's excessive speaking activity show a number of samples made up by means of the same somatism, but very diverse in structure, for example: держати язик далеко від розуму (4, р. 975); на весь язик (4, р. 975); язик без кісток (4, р. 976); проворний на язик (4, р. 976); язик добре підвішений/ причеплений/ прив'язаний (4, р. 976); язик поза вухами теліпається (4, р. 977); язик розв 'язався (4, р. 977); язик як помело / лопатень / млин (4, р. 977); вертіти / дзигороти / дріботіти / лопотіти / плескати / теліпати / тріпати язиком (4, p. 978). We can assume that Ukrainians pay much attention to the amount and value of spoken information. Having such a number of these phraseologisms represented mostly in the condemned manner while describing person's talkativeness, it can be concluded that excessive meaningless speaking activity is criticized by our nation.

The opposite characteristic of a silent or not very sociable person is also represented by the idioms using the central elements the names, nominating the organs responsible for the speaking activity as "tongue", "lips", "mouth": to hold one's tongue $(6$, p. 103$)$; to lose tongue $(6$, p. 102); to have one's lips sealed (6, p. 101); to bite one's lip (6, p. 90). Ukrainian equivalents also show the same verbal idiomatic constructions such as: держати язик за зубами (6, р. 975); зав'язати язик (6, р. 975); як води в рот набрав (6, р. 977); затуляти рота (6, p. 762); забути язика в poті (6, p. 762); ні пари з вуст (6, p. 161).

Talkativeness is usually accompanied with another characteristic such as excessive curiosity. English phraseological units as well as Ukrainian ones mostly describe this trait of character as a negative one. The scope of analyzed items shows that the central somatic elements in the structure of idioms defying inquisitiveness are the following: "nose", "ears", "eyes": to poke one's nose 
(6, p. 112); big nose (6, p. 202); nosy packer (6, p. 202); be all eyes lears $(6$, p. 88). The distinguished English phraseological units are built according to the structures "verb + noun" or "adjective + noun" accompanied by additional components such as prepositions or articles. It should be noted that the English nominative constructions manifest the metonymic meaning transition and simultaneously describe his / her character. In addition these idioms can hardly be translated into Ukrainian that can cause certain difficulties for non-native speakers while comparing two languages.

This trait of character is also described in the folk tradition of our nation. However analyzing Ukrainian idioms it can be concluded that firstly these samples are represented mostly by the full sentences including the key somatic component "nose": Не сунь свого носа до чужого проса (1, p. 98); Приткне носа і до нас (1, p. 398); Лучче $б$ глядів свого носа, ніж чужого проса $(5$, р. 426); $B$ чуже просо не тич носа (5, р. 429); Не сіяв проса, не тикай носа (5, p. 429). Secondly they contain a certain piece of advice, warning the person from excessive inquisitiveness.

Comparing idiomatic expressions in both languages we come to conclusion that the majority of illustrations show the similar structure and meaning. Above mentioned idioms can be used in comprehending stylistics issues of both languages showing their similarity and peculiar differences. Comparing the following examples such as: heart of stone - кам'яне серие or hot-headed гаряча голова the specificity of metonymy meaning formation can introduced. Typical grammar and component peculiarities are easy to be explained, for instance compound word formation describing person's traits of character. However it should be taken into account that certain samples show complete difference in the structure and hardly can be compared to the native language units (nosy packer Не сунь свого носа до чужого проса).

Conclusions and perspectives of further scientific research.

In this research we have made an attempt to focus on describing the structure and meaning differences of somatic idioms in English and Ukrainian. The analysis has shown that both languages manifest a great variety of samples containing somatic nominative components such as "eyes", "ears", "lips", "nose", 
"mouth", "heart", "tongue", "blood". Additionally it has been stated that revealing human traits of character in particular kindness, anger, talkativeness, silence, curiosity these phraseologisms represent certain variations in their meaning as well as their structure. We have also concluded that such idioms can be a well designed material for illustrating stylistic differences and peculiarities in both languages. For our further studies we leave the issues outlining the peculiarities of English and Ukrainian phraseologisms defying traits of character containing nominative animistic elements.

\section{Література}

1. Жайворонок В. В. Знаки української етнокультури : словник-довідник. Київ : Довіра, 2006. 703 с.

2. Мойсеєнко Л. Соматизми в українській, німецькій та польській мовах із компонентом найменування "частина тіла людини". Київські полоністичні cmyдii. 2015. T. XXVI. C. 410-415.

3. Патен I. Соматичний компонент у складі фразеологічних одиниць зі значенням переміщення у просторі (на матеріалі української, польської та англійської мов). Проблеми гуманітарних наук. Серія “Філологія”. 2015. Вип. 36. С. 88-96.

4. Словник фразеологізмів української мови / уклад. В. М. Білоноженко та ін. Київ : Наук. думка, 2003. 1104 с. $768 \mathrm{c}$.

5. Українські прислів’я і приказки / уклад. М. Номис. Київ : Либідь, 1993.

6. Oxford Dictionary of Idioms / ed. J. Siefring. New York : Oxford Univerity Press, 2004. 340 p.

\section{References}

1. Zhaivoronok V. V. Znaky ukrayinskoi etnokultury : slovnyk-dovidnyk. Kyiv : Dovira, 2006. $703 \mathrm{~s}$.

2. Moiseienko L. Somatyzmy v ukrayinskiy, nimetskiy ta polskiy movah iz komponentom naymenuvannia "chastyna tila liudyny". Kyivski polonistychni studii. 2015. T. XXVI. S. 410-415.

3. Paten I. Somatychnyi komponent u skladi frazeolohichnyh odynyts zi znachenniam peremishchennia u prostori (na materiali ukrayinskoi, polskoi ta anhliiskoi mov). Problemy humanitarnyh nauk. Seriia "Filolohiia". 2015. Vyp. 36. S. 88-96.

4. Slovnyk frazeolohizmiv ukrayinskoi movy/uklad. V. M. Bilonozhenko ta in. Kyiv : Nauk. dumka, 2003. $1104 \mathrm{~s}$.

5. Ukrainski prysliviia i prykazky / uklad. M. Nomys. Kyiv : Lybid, 1993. 768 s.

6. Oxford Dictionary of Idioms / ed. J. Siefring. New York : Oxford Univerity Press, 2004. $340 \mathrm{p}$. 